\title{
The Future of Minorities in Post-ISIL Iraq
}

\section{Zaianddin Mawlood Khidhir}

Department of International Relations Actual Classification, Institute of International, Political and Regional Studies, Corvinus University of Budapest, Budapest, Hungary.

E-mail: zainaddin.mawlood@uor.edu.krd

\section{Rostovanyi Zsolt}

Department of International Relations Actual Classification, Institute of International, Political and Regional Studies, Corvinus University of Budapest, Budapest, Hungary.

E-mail: rostovan@uni-corvinus.hu

\section{Zubir Rasool Ahmed}

Department of International Relations, College of political Science, Salahaddin University, Erbil, Kurdistan Region, Iraq.

E-mail: zubir.ahmed@su.edu.krd

\section{Abstract:}

The period after June 2014 has seen forces from the Islamic State of Iraq and the Levant (ISIL), an armed group, spread quickly across Iraq. This process has led to massive displacements in which affected over two million people. Indeed, the primary targets of ISIL have been religious and ethnic minorities. Some of these groups include Yazidis, Shabak, Kaka'i, and Christians. Also, ISIL has abducted or injured many people, with thousands also killed. Examples of adverse actions that the armed group has committed include severe human rights abuses such as the looting of property, the abduction of children, the destruction of places of worship, sexual enslavement, rape, forced conversion, and summary executions. Whereas the period before the insurgency group's entry still witnessed minorities exist as a vulnerable group, the violence led by ISIL has threatened to eliminate them permanently from regions such as the Nineveh Plains, have lived in these areas for several centuries. The main question 
purpose of this paper is to examine the future status of minorities in post-ISIL Iraq? ISIL. I will argue that although ISIL had been defeated in Iraq, their impact will be critical on Iraqi Minorities Even after the demise of ISIL. Currently, informal settlements, abandoned buildings, and camps in which the displaced persons live reflect deteriorating humanitarian conditions. With international agencies experiencing limited resources and also the government failing to offer an effective response, most of the international displaced people (IDPs) ${ }^{1}$ do not have enough shelter, health care, water, food, and other essential items. Indeed, most vulnerable groups include children and women. At a time when the majority are contemplating emigration out of Iraq, their survival in the immediate and far future rests upon collaboration among four groups that include the international community, the Iraqi government, Kurdish authorities, and minorities themselves. Some of the specific areas that need to be addressed include the asylum dilemma, reconciliation and restoration, preventing future abuses, legislation, and humanitarian issues.

Keywords: Minority, ISIL, Humanitarian Crisis, Armed Conflict, International Law, KRI, The Federal Government of Iraq.

\section{Introduction:}

Despite the successful retaking of Iraq from the Islamic State (ISIL), minorities are diminishing continuously, having experienced human rights abuses disproportionately. Even before the fall of Mosul, these groups continued to fear for their future amidst the absence of clear security measures through which returns could be encouraged, the region rebuilt, and the communities protected, a situation worsened by competing land claims (Ali, 2017). In a region such as the Nineveh Plains, the fate of Christianity continues to exhibit geopolitical significance. For healthy and liberal democracies, research suggests that their features lie in the protection of minorities, as well as the ability to provide room for these groups to engage in societal affairs freely (Ali, 2019). The implication is that the existence of religious minorities in a region plays a crucial role whereby it tests the degree to which a country could tolerate pluralism (Cetorelli and Ashraph, 2019). In Muslim-majority zones, the extent to which Christians could thrive and survive reflects the presence or absence of viable democracy in those areas (Ali, 2019). Currently, a grim outlook characterizes Iraq, a similar trend that continues to be witnessed in other nations with historic Christian populations - such as Turkey, Syria, and Egypt

\footnotetext{
${ }^{1}$ Internally Displaced Persons (IDPs)
} 
(Crone, 2015). In these places, many scholarly investigations avow that Christians have continually faced routine violence, government-sanctioned intimidation, and discrimination (UN Security Council Resolutions: S/2019/878).

However, the U.S. government has emerged as a powerful and influential early that has provided notable support to Christians in the Middle East, a decision that dominates American foreign policy. Particularly, significant investment has been extended to the Nineveh Plains (Dietrich and Carter, 2017). Despite these efforts and also the provision of room for Christians wishing to remain in their home countries to do so, the Nineveh Plains has seen an increasing number of families remain ambivalent relative to their future in the region. The eventuality is that there is support from Washington, but Christians in the Nineveh Plains remain vulnerable. Also, it is evident that the decision on whether the families will opt for or against staying in the region will determine the survival of Christianity in an otherwise area where it first gained root.

This paper will thoroughly examine the future status of minorities in Iraq. Moreover, are minorities, especially those inhabiting the Nineveh Plains, are on the edge of extinction. Another question that remains debatable is whether there should be international intervention to ensure that through Article 125's implementation in Iraq, they (minorities) realize their constitutional rights and how can international prosecution became a platform to address the situation

With interest in and the presence of powerful players in this area, how Christians will constantly work and ensure that they succeed in navigating the complicated network of political and sectarian interests remains an inconclusive debate. In this study, the central purpose is to investigate issues and the fate of Christians and other ethnic minorities in the Nineveh Plains, ranging from their dream for self-governance to the displaced nightmare. The rest of the paper is organized in such a way that the second section focuses on the process of uprooting and displacing minorities throughout Mesopotamia while the third section strives to give insight into the debate of the existence of minorities versus the legal framework. The fourth section will focus on the future of minorities and possible solutions, culminating into a conclusion that will recap the key insights gained from the study and, in turn, provide room for the recommendation of future research regarding the central subject under investigation.

\section{The Uprooting and Displacement of Minorities in Mesopotamia}

\subsection{The Coming of ISIL $^{2}$ and the Discriminating of Minorities}

In Iraq, minorities have experienced war for about 16 years. Due to the devastating nature of this adversity, an increasing number of these communities remain on the verge of disappearance (Donabed, 2015). Not only have millions fled, but tens of thousands of members of minority groups have been killed (Gardner, 2016). According to the Office of the United Nations High Commissioner for Refugees (UNHCR), the Iraqi census of 1987 showed 1,400,000 Christians living in Iraq, but in 2006 it was estimated that there were fewer than 1,000,000 Christians living in Iraq (UN Aug. 2007, 59). However, by 2016, the population was estimated to be less than 250,000 (Helfont, 2018). After a U.S.-led coalition toppled Saddam Hussein, the country has continually been engulfed by sectarian tensions and civil conflicts. The year 2014 also saw militants belonging to the Islamic State (ISIL) declare a caliphate, having captured Syrian and Iraqi swathes (Hanish, 2015).

${ }^{2}$. Islamic State of Iraq and the Levant. 
Some of the notable minorities that have been affected disproportionately include Kaka'i, Christians, Shabak, Turkmen, and Yazidi (Helfont, 2018). In the ancient Mesopotamia, one of the indigenous groups, Yazidis, has been affected adversely whereby most of the followers of Yazidism have been persecuted and killed because of accusations of "devil" worshipping, having predated the Abrahamic religions (Ibrahim, 2018). Whereas the population of this indigenous group was about 700,000 by 2005 (Johnston, Alami and Clarke et al., 2019), recent demographic statistics suggest that it has been reduced to about 500,000 people in Mesopotamia (Kaya, 2019). In Iraq's post-ISIL era, many Yazidis have been enslaved or displaced. For instance, about 6,800 Yazidis were kidnapped to be used as fighters or sex slaves, while 3,100 were killed around Mount Sinjar (Millare, 2019).

In Mesopotamia, the Iraqi Turkmen (who constitute the third-largest minority community) have also been subjected to displacement. Whereas many of these members are Sunni or Shi'a Muslims, a small minority documented to be about 30,000 are Christians. In a quest to provide room for Arab communities, many Iraqi Turkmen have been displaced, with ISIL killing and also subjecting most of the women to sexual abuse. Indeed, Tal Afar has been one of the worst-hit districts in the neighborhood (Mosul Study Group, 2017).

Indeed, it is evident that the repercussions of the havoc caused by ISIL, the ensuing security vacuum, and the Iraqi civil war have seen minorities in Mesopotamia issues ranging from arbitrary punishments, abductions, gross human rights abuses, and civilian casualties to the destruction of cultural heritage, displacement, and the use of chemical weapons (O'Driscoll, 2017). In particular, recent observations suggest that over two million people belonging to the minorities have been displaced in the area and its neighborhood. The situation seems to have been worsened by the beginning of the Mosul offensives that saw over 441,000 individuals uprooted from their homes in May 2016 alone. Of these, only 105,000 have been reported to return (Oehring, 2017). It is also imperative to highlight that in some of these operations, ISIL deployed chlorine gas. The uprooting and hundreds of abductions have, therefore, led to the brainwashing of most of the young boys with ISIL propaganda while many women have been forced into sex slavery for ISIL members (Robinson, Engel and Johnston et al., 2017). Thus, a deeply complex situation characterizes Mesopotamia and its neighborhood, with a lasting solution to the fate of minorities in the region yet to be comprehended.

\section{2 the Minorities and Iraq's Intervention Minority Rights in the Context of the Iraqi Constitution}

Iraq's interim constitution, which has been acknowledged by some scholars as being impressively liberal (Rubaii, 2019), was produced at a time when the country was under great pressure of time (Salloum, 2017). Some of the major constitutional principles governing the guideline include extensive minority vetoes and federalism. The Constitution was adopted on 15 October 2005, coming in the wake of a highly disputed referendum (Shea, 2016). In Article 2, the Constitution states that all individuals (including minorities such as Mandean Sabeans, Yazidis, and Christians have full religious rights and freedom of religious belief and practice. Also, Article three acknowledges explicitly that Iraq is a country of multiple sects, religions, and nationalities (Iraq's Constitution of 2005). In Article 4(1), the constitution guarantees Iraqis the right to ensure that their children are educated in mother tongue in government educational settings, including minorities such as Armenian, Syriac, and Turkmen (Iraq's Constitution of 2005). Hence, the Constitution promises minorities the right to mother tongue education. It is also notable that discrimination is prohibited, as specified 
in Article 4. Particularly, the Constitution states that before the law, Iraqis are equal and that discrimination against persons based on social or economic status, opinion or belief, sect, religion, color, origin, nationality, ethnicity, race, or gender is prohibited (Zaman, 2016). In Chapter 4 of Article 125, the Constitution guarantees educational, cultural, political, and administrative rights to members of various nationalities, minorities such as Assyrians, Chaldeans, and Turkmen included (Ali, 2017). Overall, the 2005 Constitution of Iraq is seen to strive to build on the 1932 Declaration and provides several rights to minorities, with the theme of equality dominating provisions in the legal framework. A subject that becomes important to investigate and unearth insights is the degree to which the Constitution has aided in responding to and addressing minorities' problems since 2003, especially in the wake of growing disasters that continue to befall Iraq.

\section{3 the Minorities' Loss of Original Lands and Properties}

Whereas the majority of international groups have focused their attention on the conflict between Arabs and Kurds, especially in Kirkuk, an oil-rich city that houses disputed authorities, Nineveh forms a leading battlefront in the conflict (Ali, 2019). In particular, Nineveh, based on recent statistics, is the second-most populous province in Iraq. Also, the province hosts historical minority groups in unique concentration (Cetorelli and Ashraph, 2019). On the one hand, the Constitution specifies that Nineveh is under the country's central government's jurisdiction. On the other hand, Kurdish authorities are out to reshape the province's reality, especially because most of its ethnically mixed communities are located just east and north of Mosul, a provincial capital in the little-known Nineveh Plains.

Hence, the political and military presence of the Kurdish in the Nineveh Plains is so pervasive that they have secured one village after another. It is also notable that even with stiff resistance from minority communities and Sunni Arabs, Kurdish authorities in the Nineveh Plains have either joined or backed insurgency (Crone, 2015). With the insurgents characterized by extremist elements, communities such as Shabak, Yazidi, and Chaldo-Assyrians have been attacked viciously, as well as labelled as infidels, devil worshippers, and crusaders, respectively (Dewachi, 2017).

Therefore, most of the minorities have lost their original lands. For example, 2008 events in Mosul, which involved orchestrated and systematic campaigns of violence and targeted killings, witnessed over 12,000 Chaldo-Assyrians displaced, with about 40 killed (Dietrich and Carter, 2017). Also, there the month of August 2007 saw Nineveh's simultaneous truck bombings account for over 300 Yazidi deaths, with over 700 wounded and displaced in one of the worst single attacks targeting civilians (Donabed, 2015). At a time when there is a growing debate of whether or not to establish a province for Christians and other minorities in the Nineveh Plains as a safe haven, wishes of the majority of the inhabitants are lost. Particularly, most of the inhabitants have been displaced forcibly.

For instance, recent surveys by the Nineveh Center for Research and Development suggest that more than 4,000 Christians and Yazidis were displaced in 2014, with Syriacs and Chaldeans dominating the Christian group (Gardner, 2016). Additional research suggests that whereas most of the minority community members who have been displaced would wish to return (five percent), a significant proportion (42 percent) prefer leaving Iraq and securing safe havens abroad (Hanish, 2015). For the majority of those who are against returning, the dominant reason cited involves neighbors' betrayal via collaboration with ISIL (Helfont, 2018). 
The disputes between the Kurdistan Regional Government (KRG) and Baghdad central government is also seen to one of the factors that makes minorities' situation worse. According to Ibrahim (2018), most of Assyrian Christians have been evicting from their homes due to fighting ISIL. As asserted by sections of Yazidi Human Rights Organization International representatives, Yazidis have also been affected adversely and suffering at the expense of defeating ISIL (Johnston, Alami and Clarke et al., 2019).

Overall, the observations above suggest that most of the minorities in the disputed territories of the Nineveh Plains have lost their land and rescued under the control of Kurds as refugees. If there is not any serious struggle to normalize and rebuild the Nineveh plain infrastructure, this might mark the minorities' permanent loss of their original land.

\subsection{Minorities and the Danger of Annihilation}

Annihilation refers to a state of total defeat or destruction of an individual, a community, or a system. In the Iraqi context and the equation of the inconclusive debate concerning the fate of minorities in the Nineveh Plains, the subject of possible annihilation implies discussions about possible extinction or total destruction. In particular, the emerging question is, are minority communities in this disputed terror under the danger of extinction?

In the Nineveh Plains, discriminatory laws, lack of opportunities, and insufficient security continue to deprive minority community members (Kaya, 2019). These members neither enjoy fundamental rights that could guarantee their existence nor receive adequate protection by the Iraqi's authorities there (Millare, 2019). For these minorities, life has been turned to a nearly impossible mission, coming at a time of pervasive rejection of their religious and ethnic elements, as well as persistent violence. Since 2003 therefore, in response to these problems, a huge exodus has occurred, a trend marking the greatest threat to the minorities' survival in the disputed territory.

In about 17 years, over 50 percent of the Assyrians have left the region. In regions such as Syria, Jordan, and other parts of the world, Iraqi refugees (mostly from the disputed territory) are about two million, yet 30 percent of these are minorities (Mosul Study Group, 2017). According to O'Driscoll (2017), adversities such as growing religious intolerance, difficulties in education, financial hardship, and unemployment characterize most of the minorities' daily life, especially Assyrian Christians. Oehring (2017) observed further that subjection to a pattern of neglect, marginalization, and official discrimination has made most of the minority community members to perceive that they are no longer tied to or part of the Nineveh Plains, treating themselves as persons excluded from civil society.

Notably, most of the inhabitants of the Nineveh Plains are indigenous minorities, yet problems such as underdeveloped structures, corruption, political mismanagement, and unemployment threaten their existence. Robinson, Egel and Johnston et al. (2017) stated that with desperation setting in, most families have remained restless, moved from place to place, and endlessly expressed the desire to leave the region. Focusing on the current situation in Iraq and whether or not minorities are on the edge of annihilation, a study by Rubaii (2019) revealed that most of the affected community members liken a disputed region such as the Nineveh Plains to a graveyard for religious and ethnic minorities, findings that were similar to those reported by Salloum (2017), who noted that most of the inhabitants perceive issues in the region as the occurrence of another Holocaust. With the minorities unsure, delicate, and precarious, a question that is worth examining is whether decades of strive might permanently render them invisible in the immediate future. 
In response to the question of whether minorities, especially those inhabiting the Nineveh Plains, are on the edge of extinction could be better approached based on the shift in demographics of the specific groups that have been targeted, especially by ISIL and other militants. For Christians, livelihoods and homes have been destroyed, with ISIL attempting to ensure that across the territory and the rest of Iraq, any memory about Christianity is destroyed completely. Whereas country estimates suggest that Christians have reduced from 1.5 million (before 2003) to about 150,000 to 200,000 in Iraq, the situation in Nineveh seems direr (Helfont, 2018). In this area, Shea (2016) observed that only about 40,000 Christians displaced internally have returned to the territory, their ancient homeland. Even for this group that has returned, problems of violence, intimidation, and discrimination are prevalent, with Iran's backing of the militias making their hopes of cling onto their property and land fade (UNHCR, 2019).

In Sinjar province, Yazidis have been worst hit. With ethnic cleansing that ISIL launched, recent statistics indicate that about 2,900 Yazidis are yet to be traced, with over 400,000 living in displacement (Wainscot, 2019). Also, 68 heritage and religious sites have been destroyed, with 70 mass graves yet to be exhumed. Indeed, these sample statistical analyses suggest a high rate of population decline among minorities in the Nineveh Plains and other parts of Iraq. In relation to the question of potential annihilation, the outcome will depend on how the militias and the anti-militia groups will succeed in their agenda. Should the recurring cycle of violence persist, the minorities' extinction in the Nineveh Plains, a disputed territory, is possible. However, if strategies such as establishing a province for minorities as a save heaven are implemented successfully, the population of the affected communities might be restored gradually.

\subsection{Kurdistan Region as a "New Safe Heaven" for Minorities}

In Iraqi Kurdistan, the government and people have played a leading role in ensuring that all religious minorities, Yazidis, and Christians are protected. Whether non-Muslim or Muslim, people have gained freedom in such a way that the practice of their religion has remained open (Zaman, 2016). With ISIL taking control of a vast region in the northern part of the country in 2014, KRG has proved to be a safe haven for providing assistance and vital security. Statistically, the safe haven has attended to about two million Iraqis displaced internally, with Yazidis and Christians dominating this population (Joint Crisis Coordination Centre). In the Kurdistan region, 20 percent of the people are either internally displaced persons (IDPs) or refugees. Also, the most affected province is Dohuk, where some villages have seen the ratio between IDPs, and locals stand at 1:1 (Ali, 2019). With billions of dollars spent on addressing the IDPs' needs, some of the services that KRG has provided include camp monitoring, camp management, education, security and protection, electricity, water, and health services (Cetorelli and Ashraph, 2019).

Before an ISIL offensive attack, Mosul's Christian population was around 10,000. However, most of these families fled and sought refuge in Kurdistan to be protected by the local Peshmerga army - from hard-liner Sunni fighters (Crone, 2015). Indeed, Kurdistan, has proved unique from the rest of the Iraqi zones whereby it has preserved co-existence among diverse communities successfully. For oppressed minorities, therefore, the region reflects a safe haven and a "new heaven." However, it is worth noting that in the wake of northern Iraq's previous power vacuum, the Peshmerga goes beyond Kurdistan's borders (Dewachi, 2017). Whether this extension of the influence might hurdle the successful assurance of community co-existence in the region as the central government sees it as a threat and does not providing help to return minorities. 
Indeed, Kurdish forces have protected refugees in Bashiqa town, whose distance of separation from Mosul stands at about ten kilometers. Despite this promising trend in Kurdistan, several issues pose a dilemma in relation to the existence of refugees of minority communities in the region and whether or not efforts should be made in the post-ISIL era to return them to their ancestral lands. Specifically, one of the issues is how the military, economic, and political assets could be mobilized to ensure that on the Nineveh Plains, a multi-ethnic province is established. Another issue that is yet to receive in-depth analysis is whether and how a contiguous safe haven could be created, encompassing the Nineveh Plains, Tal Afar, and Sinjar. Should this project be successful, it remains inferable that there might be a significant transition to realize a self-administered province or various provinces in Iraq.

However, prospects of such efforts come at a time when there are also mixed opinions among the minorities themselves, with some arguing in favor of staying while others are keen to emigrate. Of importance to note is that Kurdistan has, indeed, played a crucial role and even ensured that the U.S. foreign policy regarding the criticality of this safe haven in fulfilling its (United States') operational needs of fighting ISIL is achieved. With the U.S. strategy concretized and strengthened, whether the stability might spread to the rest of Iraq or remain or only be felt in Kurdistan remains unknown. Overall, it is worth acknowledging that Kurdistan has transitioned from a disputed zone to a safe haven for minorities and that its existence as a destination for most of the refugees and IDPs has fulfilled three specific interests of the U.S. these interests include territorial interests (in which ISIL and its offshoots have been weakened and also promised to protect disputed lands during post-ISIL), political interests (in which minorities might enjoy greater political participation after strengthening cohesiveness and diversifying the region's political landscape), and geopolitical interests (in which expansionist foreign powers have been blocked and also demonstrated that good governance and coexistence is possible).

\subsection{KRI and Challenges Facing Refugees and IDPs}

As highlighted above, the Kurdistan Region of Iraq (KRI) has played a crucial of achieving diversity and coexistence among communities, a trend that has seen the region house most of the minorities fleeing religious persecutions. However, the "new heaven" has not gone without direct challenges with which the minorities have had to grapple. When Mosul was seized by ISIL, hundreds of thousands of individuals of different ethnicities fled to KRI to secure shelter in a mix of parks, schools, mosques, and hotels (Dietrich and Carter, 2017). With a significant increase in population, checkpoints have had to be closed regularly, keeping thousands of individuals waiting for periods as long as five days, a problem exacerbated by lack of adequate communication and also water, food, and shelter (Donabed, 2015). Similarly, access rules have been reported to be applied differently based on the religion and ethnicity of the affected persons. For instance, Gardner (2016) observed that for Christians, Kurds, or individuals with sponsors within Kurdistan, they are likely to pass easily while most of the other Iraqi individuals have been sent to temporary holding sites, and this procedure is done for security and safety reasons to keep the region from entering terrorists. At checkpoints, access points have also been observed to be unpredictable (Hanish, 2015). This is also the result of the war of terror; otherwise the terrorist penetration could not be avoided easily if the gate wide open for everyone.

For researchers who have focused on the humanitarian situation in the KRI, the region's absorption capacity has also been questioned, with displaced populations coming in high numbers - at a time when the KRI is also experiencing limited and decreasing humanitarian aid, increasing poverty, and deteriorations in socio-economic conditions (Helfont, 2018). Some of the specific problems arising from a large number of displaced persons in KRI's urban zones include a 
significant decline in the standards of living, increased job competition, and strained local services and infrastructure (Ibrahim, 2018). Similarly, most of the IDPs in informal settlements (such as abandoned or unfinished buildings) and camps have experienced extreme weather conditions, as well as poor sanitation infrastructure and inadequate water (Johnston, Alami and Clarke et al., 2019). From an employment perspective, many of these IDPs can only secure casual work, implying that the majority do not have a regular income (Kaya, 2019). Other areas where problems have persisted include education and health care (Millare, 2019). Even in the wake of post-ISIL, many minorities such as Yazidis have not managed and are not welling to return to areas such as Sinjar District due to lack of Iraqi's plan and support for the community. Some of these issues include safety concerns, lack of financial means to return, fear of discrimination, the damaging or destruction of their houses in the Nineveh Plains, and presence of mines (Mosul Study Group, 2017). Others include persisting community tensions and lack of basic services and livelihoods (O’Driscoll, 2017).

\section{Minorities and the Legal Framework}

\subsection{Analyzing Article 125 of the Iraqi Constitution}

From Article 125, the Iraqi Constitution guarantees educational, cultural, political, and administrative rights of different nationalities, including Assyrians, Chaldeans, Turkomen, and other constituents (Oehring, 2017). Based on this provision, Robinson, Egel and Johnston et al. (2017) stated that the aim is to ensure that a truly pluralistic and democratic Iraq is realized, especially due to the need to provide room for minorities to remain Iraqi society's productive elements, as well as live securely in a region such as the Nineveh Plains. However, a debate that is yet to be analyzed comprehensively is whether external parties such as the U.S. and other decision-makers in the West should acknowledge the criticality of intervening to ensure that for Iraq's persecuted minorities, protection and political space are provided and that they gain an opportunity to advance the agenda behind Article 125 of the Constitution. For Yazidi, Turkmen, Shabak, Kaka'I, and Christians the policy or legal framework promises them survival. With the dilemma of if and how the U.S. and its allies should intervene or collaborate with Iraqi government to implement the stated Article yet to be solved, minorities remain victims of wide-scale ethnoreligious cleansing, yet there is urgency for Iraq to be transformed into a fully federal state, a state of stabilization that depends on how far Article 125 will be enacted.

For studies that have focused on the possibility of minorities succeeding in achieving the goal of Article 125, a key subject has been whether and how a separate administrative region could be created while ensuring that the process abides by the Article's provisions (Rubaii, 2019). From a federal perspective, debates about autonomy are complex in Iraq (Salloum, 2017). Firstly, "autonomy" could be seen to reflect aspects such as secessionism, devolution, or decentralization. On the other hand, federalism could be seen to partition the country, a trend that Shea (2016) cautioned that it could translate into violence and regional instability. For minorities, entering a federalism dialogue to implement Article 125 to the latter also comes with challenges, especially regarding the credible threat of force, as well as lack of power. To achieve their constitutional rights, therefore, minorities might have to rely on the respect for and the development of the rule of law, which has proved difficult to achieve due to ever-growing ethnic tensions even during the post-ISIL era.

With minorities seen to be limited by the aforementioned issues, another question that remains debatable is whether there should be international intervention to ensure that through Article 125's implementation in Iraq, they (minorities) realize their constitutional rights. Recently, the U.S. invested in religious and ethnic minority assistance in 
Iraq and targeted the area of political, economic, and social empowerment. In particular, 8.5 million dollars have been provided to assist with legal support and offer psychological services, as well as support initiatives through which evidence about abuses of human rights might be collected. Also, the funding has aimed to provide access to economic opportunities for minorities, offering livelihoods support, strengthening the rule of law, increasing access to justice for children, and increasing minority representation in provincial and local government (UNHCR, 2019). Whereas Wainscot (2019) documented that these efforts reflect a promising step via international intervention, Zaman (2016) cautioned that they are reactive and that Article 125's full implementation might be felt only if minorities, especially in the Nineveh Plains, will be empowered and well placed to handle the aforementioned initiatives with little or no international intervention. Hence, the mixed outcomes demonstrate that there is international intervention, but an ideal situation that might see minorities fully enjoy their rights as guaranteed by Article 125 of the Iraqi Constitution is that in which the initiatives mentioned above will have the implementing groups dominated by representatives from the affected minority communities, rather than international persons and organizations.

\subsection{ISIL The Minorities' position in Post ISIL}

The fall of Mosul was witnessed in June 2014, upon which ISIL assumed full control of banks, and military and administrative infrastructure. Following this seizure of the region, panicked mass evacuations followed. Across Iraq, the worst hit districts included Tal Afar, Diyala and Salah al-Din governorates, and Sinjar, Al-Hamdaniya (Ali, 2017). For Christians (who dominate the most affected and targeted groups), one of the main issues that have been reported involves gender-based and sexual violence. In the study by Ali (2019), it was documented that ISIL militants have perpetrated enslavement, abductions, rape, sexual abuse, and other sexual violations on children and women across Iraq. In affirmation, Cetorelli and Ashraph (2019) stated that sexual violence has been employed as a tool of coercion and terror, including Beshir, a Turkmen majority zone. Additional UN sources suggest that some Yazidi women who have been captured have been forced to marry ISIL fighters or convert to Islam. Even for those who might have resisted, Crone (2015) stated that the majority would be sold into sexual slavery. Thus, these reports suggest that after the fall of Mosul, most of the minorities across Iraq, especially Yazidi, Turkmen, Shabak, Kaka'I, and Christians who were captured by ISIL fighters, have experienced human rights violations. Even after the region was regained, lack of adequate security forms one of the threats inhibiting both reconstruction and population returns.

Another impact that the fall of Mosul has had on the lives of minorities includes the destruction of religious and cultural property. According to Dewachi (2017), the period after the fall of Mosul saw ISIL engage in a systematic campaign aimed at eradicating the identity, history, and culture of religious and ethnic communities in regions that it controlled. As contended by Dietrich and Carter (2017), monuments, buildings, and sites of immense historical, cultural, and religious importance have been destroyed. They include texts of value to Iraqi minorities, irreplaceable ancient manuscripts, tombs, and churches (Donabed, 2015).

Another perspective from which the life of minorities could be explained after the fall of Mosul, for example, involves the current situation of IDPs. According to Gardner (2016), ISIL forces' advancement across central and northern Iraq have caused a catastrophic humanitarian situation. For instance, most of the displaced communities originating from the Nineveh Plains are spread across the country's governorates and exceed 2.25 million, with KRI hosting about 1.5 million IDPs (Joint Crisis Coordination Centre, 2020) . For these IDPs, numerous studies document significant challenges with 
which they have had to contend, including a severe shortfall in primary humanitarian aid, limited services, dispossession, and lack of legal documentation (Hanish, 2015). With the latter challenge causing a lack of identification, Helfont (2018) stated that the tertiary effect is that it makes several services unavailable to the IDPs, as well as restrict their movement.

In summary, three major issues characterize the life of minorities after the fall of ISIL in Iraq. These issues include a destruction of religious and cultural property, human rights violations, and a catastrophic humanitarian situation.

\subsection{Bringing ISIL to Justice: Towards Establishing International Tribunal}

Whereas events in Iraq (especially in the Nineveh Plains) depict a volatile situation, a serious effort through which perpetrators could be brought to justice is yet to be made. For scholarly investigations that have analyzed the views of Iraqi government officials and jurists, the majority avow that the country's judicial system has proved relatively inadequate and not well placed to prosecute the crimes successfully (Ibrahim, 2018). A question that arises is whether international prosecution is the best platform to address the situation and if so, the manner in which global law could blend with provisions in Iraq's Constitution to realize the intended goal of justice.

From the perspective of international law, war crimes are prohibited (Johnston, Alami and Clarke et al., 2019), yet Kaya (2019) observed that ISIL commanders and forces have committed them. Whereas the nature of the armed conflict could be non-international, Iraq ratified treaties regarding international humanitarian law in the entirety. As asserted by Millare (2019), some of these treaties include the prohibited means of warfare and weapons, the 1949 Geneva Conventions, the 1987 Convention against Torture, the 2000 Optional Protocol regarding the use of children in armed conflict, and two Additional Protocols of 1977 linked to the 1949 Geneva Conventions.

It is also worth noting that customary international law regarding war crimes binds Iraq. According to the Rome Statute for ICC's Article 8, pre-existing treaties are codified, and Iraq remains a party. It is further notable that relative to crimes against humanity, the customary international law binds the Genocide Convention, which Iraq has ratified (Mosul Study Group, 2017). Based on the nature of armed conflict in this country, with crimes against humanity and genocide excluded, international humanitarian law applies if an armed conflict is confirmed (O'Driscoll, 2017). According to Oehring (2017), the existence of an armed conflict is confirmed if there is protracted armed violence between organized armed groups and governmental authorities, when force is used between states, or when organized armed groups engage in protracted armed violence between or among themselves within a state.

In Iraq, the advancement of ISIL into most of the Ninewa governorate and the assault of Mosul reflected engagements between an armed group and government authorities (Iraqi government), with armed attacks also evidenced by the use of weapons, kidnappings, killings, and property destruction (Robinson, Egel and Johnston et al., 2017). However, a dilemma emerges on whether to treat the conflict as international or non-international, especially due to lack of clarity of whether ISIL acted on behalf of another state outside Iraq. As indicated by Rubaii (2019), some of the fighters and leaders of ISIL are not of Iraqi origin. However, there is no evidence that ISIL be receiving instructions from or under the control of a foreign power (Salloum, 2017). With the involvement of the U.S., the equation becomes more complicated regarding whether to classify the armed conflict as international or non-international. However, Shea (2016) observed that whereas the U.S. was in control and authority of its forces, they (the U.S. forces) sought to support Iraqi forces to counter ISIL and that they were not attacking Iraqi forces, disqualifying the possibility of a state versus state armed conflict. As such, 
the nature of the conflict is non-international. However, several specifications in international law point to the criticality of applying guidelines in the treaties that Iraq has ratified. According to the UNHCR (2019), the need for global law application and other states' involved arises from issues such as taking hostages, directing attacks against civilians intentionally, pillaging places or towns without the owners' consent (such as the Nineveh Plains), committing sexual slavery and rape, enlisting or conscripting underage children into armed forces, murder, extermination, enslavement, and torture. Others include severe deprivation of physical liberty (especially for the kidnapped women and girls), enforced disappearance of persons, and genocide (Wainscot, 2019). With the recent regaining of Mosul, an important chapter that proves crucial to examine and one that marks the climax of the otherwise inconclusive debate about events surrounding the lives of minorities in Iraq is their future, as well as some of the lasting solutions that are worth adopting and implementing.

\section{The Future of Minorities}

With the evidence of a conflict zone in Iraq, especially in the Nineveh Plains where minorities mostly constituting Yazidi, Turkmen, Shabak, Kaka'I, and Christians are the worst-hit, the question is what next? And what is the fate in the immediate and far future, with Mosul having been regained? Notably, it is evident that many religious minority groups have responded to the armed conflict by shifting their priorities in such a way that they have deviated to focus on their immediate survival, deviating from the previous priority involving the development of a stable way of life at the family level (Zaman, 2016). In former regions where their communities lived for many centuries, these minorities have ended up leaving to live as IDPs in the rest of Iraq, with some also hoping for and contemplating possible emigration out of Iraq (Ali, 2017). This study has also established that in the wake of these hopes, minorities have not only lost their family members, possessions, and homes but also continue to operate at a time when the Iraqi government has not been relatively successful regarding effective redress and the provision of adequate humanitarian aid, as well as the failure to achieve a safe means through which the displaced communities could return to a region such as the Nineveh Plain safely. For the majority of discussions around the world, Ali (2019) documented that focus has been on how ISIL-controlled territories' continued atrocities could be prevented and also ensure that in large areas in the northern zone, the collapse of governance is resolved. As such, a gap that has been evident is that even upon successful elimination of militants in future, minority communities might have their future defined as that which is precarious. Cetorelli and Ashraph (2019) documented that if there is not a fair solution to the disputed territories between the KRG and Iraqi central government, the delicate future of the minorities might worsen. Therefore, it is important to ensure that planning and preparations are made to provide the affected communities with necessary cultural, social, economic, and political space, a step that Crone (2015) suggested that if successful, promises a continued place for minorities across Iraq.

Of importance to note is that at a time when the grip of ISIL on Ninewa, Kirkuk, Salah al-Din, and Diyala governorates is weakening, it becomes important for a clearer way forward to be developed. In this study, it is acknowledged that during post-ISIL planning, a concrete, practical, and lasting solution will be realized only if it includes consensus building among four major parties. These parties include minority communities, the international community, the KRG, and the Iraqi government. Also, the mixed outcomes that this study has established regarding the complex and delicate situation in Iraq leads to the inference that an ideal solution is that which will focus on pressing concerns that include a long-term reconciliation, economic, and administrative framework seeking to protect minorities, return issues, missing persons, property rights, and security. 
Another point that is important to note is that an ideal approach to the latest suffering, especially by Yazidi, Turkmen, Shabak, Kaka'I, and Christians in the Nineveh Plains, should be viewed from the perspective of historical discrimination that they had experienced even before 2003, and also before the armed conflict between the armed group (ISIL) and Iraqi government. For some studies, historical discrimination has played a leading role relative to the violations of human rights that these minorities have experienced, with war crimes worsening the situation and mostly conducted along this historical line (Dewachi, 2017). Therefore, to ensure that ethnic and religious minorities continue to live in Iraq safely, there is a need for a national-level inclusive vision that will ensure that the country's rich diversity is not stigmatized and that instead, it is accommodated.

\section{Recommendations}

\subsection{The Federal Government of Iraq}

\subsubsection{The Case of the Humanitarian Crisis}

To alleviate the humanitarian catastrophe in Iraq, Iraq's federal government in accordance with the KRG should emerge as a primary and responsible party and ensure that displaced Iraqis are supported through the establishment and implementation of a comprehensive strategy for addressing the humanitarian emergency. Through international support and state funding, the government should ensure adequate resource availability. Also, the government needs to allow for the issuance of credentials and identity documents on an emergency basis, especially among IDPs in different governorates, upon which the affected minorities will be better placed to access government or basic services and rations. Similarly, the federal government needs to develop a registry of missing persons to ensure that missing person claims are registered, a task that should be delegated to the Ministry of interior and human rights organizations (Redvers, 2015). Regarding the delivery and procurement of humanitarian aid, the federal government needs to initiate impartial, independent, and prompt investigation into corruption and ensure that any responsible persons are prosecuted. For victims, specialized services such as psychological counselling need to be provided, especially women and young girls who have been victims of sexual violence, as well as traumatized children.

\subsubsection{Reconciliation and Restoration}

In the post-ISIL era, there is a need for immediate planning to develop secure areas, enabling minorities to return to their lands and homes. To achieve this objective, the federal government should seek international support, especially due to the need for an otherwise costly process of infrastructure development and investment. Also, a comprehensive plan should be established to ensure that the affected minorities' returns are supported via infrastructure needs assessment and the securing of budget line items. In addition, it is recommended that Iraq and the KRI implements community-based reconciliation mechanisms toward reintegrating groups that remained with those that fled areas such as the Nineveh Plains. Applicable property documentation should also be collected to provide restitution and reparations to those who lost livelihoods and homes in Diyala, Sahal al-Din, Kirkuk, and Ninewa governorates. 


\subsubsection{Legislation}

To ensure that the mandate of the High Commission for Human Rights is implemented, the federal government in accordance with the KRG should offer relevant resource support, upon which human rights violations targeting vulnerable groups such as minorities might be monitored and reported timely. In Iraqi police and security forces, the representation of minorities needs to be strengthened, a process that needs to be complemented by the development of a special police unit whose role will be to handle sectarian, religious, or ethnic bias, as well as hate crimes.

\subsection{The International Community}

\subsubsection{Issues of Asylum}

For Iraqi refugees, there is a need for the international community to ensure that entry is allowed, especially because of the fleeing from persecution. Also, refoulement needs to be barred to ensure that the refugees, whose freedom and lives remain at risk, do not return to Iraq without proper planning (Redvers, 2015). Furthermore, policies such as background checks and asylum criteria ought to be adjusted in a way that would ensure that inconsistent identity documentation is recognized relative to the magnitude of the conflict, a situation that would see the community characterized as one that would have committed to displaced minorities' resettlement and longer-term protection.

\subsubsection{Humanitarian Crisis}

For the NGOs based in Iraq, the international community needs to provide assistance to support the initiatives' humanitarian operations. Also, financial support needs to be provided urgently to organizations such as international NGOs, Red Crescent Movement or Red Cross, and the UN system, upon which the response led by both the Iraqi government and KRG might run smoothly. Similarly, it is recommended that in the wake of extreme winter conditions, emergency relief is provided immediately, including essentials such as medical supplies, tents, water, and food. However, this intervention needs to be organized in such a way that the actors collaborate with KRI and other humanitarian groups (Joint Crisis Coordination Centre KRG, 2020).

\subsubsection{Future Abuse Prevention}

To avert future abuse, it is recommended that concrete steps are developed and implemented to curb material support and financial transfer to armed groups. Additionally, the international community should ensure that while providing military assistance, it liaises and shares intelligence with minority organizations, especially regarding the communities' security. Furthermore, it is critical that the international community abides by international human rights law and international law while taking action against armed groups in Iraq, especially while supporting the Iraqi government. 


\subsection{The Case of the Kurdish Regional Government}

\subsubsection{Reconciliation}

For KRI, priority needs to involve establishing secure areas, a step that might pave the way for the affected groups' safe return to their original lands and homes. Also, the Kurdish Drafted Constitution's Articles 36, 35, 14, and 5 ought's to be extended to ensure that Shabak and Yazidi are recognized as different identities, upon which future documentation might be easier, especially while responding to similar emergencies. Also, this step is poised to ensure that any historical injustices that these minorities might have faced and constituted to the armed groups' violations of their human rights are alleviated.

\subsubsection{The Humanitarian Catastrophe}

For the case of KRI and its response to the humanitarian crisis in Iraq, priority needs to involve children, as well as women and young girls who have been victims of sexual abuse. Similarly, the discriminatory way in which essential services have been reported to be provided needs to cease and ensure that the involved state officials are apprehended, and justice served accordingly - based on the draft Kurdish Constitution's Article 19 for the displaced minorities' winterized and adequate living arrangements, the KRI need to collaborate with donor governments and international organizations, upon which the quest to provide the needed humanitarian assistance might be realized.

\section{Conclusion}

In this study, the main objective was to investigate issues and the fate of Yazidi, Turkmen, Shabak, Kaka'I, and Christians in the Nineveh Plains as an example of Iraqi minorities' situation during and post ISIL, ranging from their dream for self-governance to the displaced nightmare. Some of the specific areas that have been investigated include the process of uprooting and displacing minorities throughout Mesopotamia, the debate of the existence of minorities versus the legal framework, and the future of minorities in Iraq, ,. From the insights gained, it is evident that the primary targets of ISIL have been religious and ethnic minorities, including Yazidis, Turkmen, Shabak, Kaka'i, and Christians. Also, some of the human rights violations that the group has committed include the looting of property, the abduction of children, the destruction of places of worship, sexual enslavement, rape, forced conversion, and summary executions. For a lasting solution, there is a need for collaboration between the international community, the Iraqi government, Kurdish authorities, and minorities. For these groups of stakeholders, issues that require attention include the asylum dilemma, reconciliation and restoration, preventing future abuses, adopting legislation, and humanitarian issues. In so doing, it is projected that the lives of religious and ethnic minorities will be improved and that a safe return, reconciliation, and infrastructural restoration might be realized. In the future, it is recommended that scholarly studies examine the feasibility, effectiveness, or impact of the recommended strategies on the restoration of the life of Yazidi, Turkmen, Shabak, Kaka'I, and Christians and other minorities in the Nineveh Plains of Iraq.

\section{Author contribution}

The first author led the research, preparation and the writing the manuscript; while the second and third authors has contributed in reviewing the study, as they are supervisor and co- supervisors of the author's PhD. 


\section{نايينداه كلمينهكان للهيّراقى دواى داعشى}

\section{زينهدين ملولود خضر}

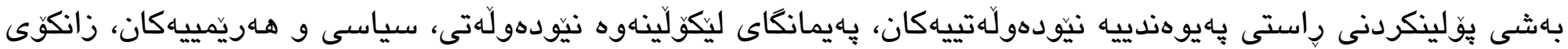
كورثينوّس له بوَداييّست، بودايِيست، هـانكاريا. zيمايل: zainaddin.mawlood@uor.edu.krd

\section{Rostovanyi Zsolt}

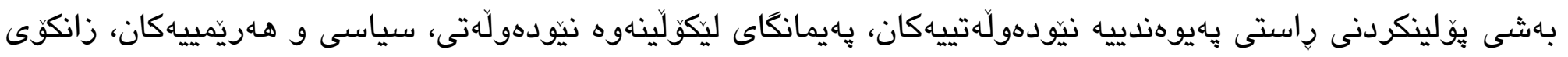

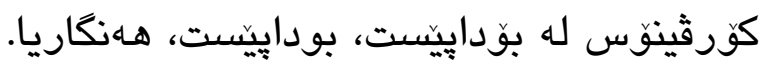

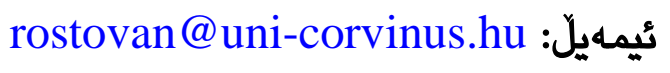

زوبيّر رِسول احمد

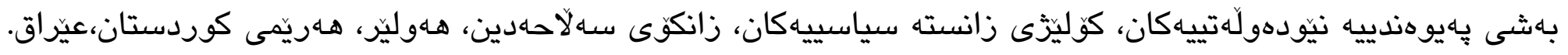
تيمهايل: zubir.ahmed@su.edu.krd

يوخته:

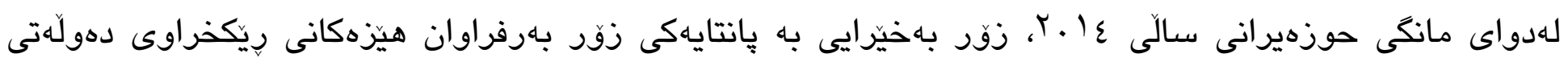

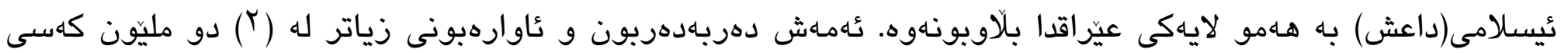
ليكهوتهوه. ئامانجى سهردكى داعش ئهمانه بون: قركردن و لهناوبردنى كهمينه ئاينيهكانى وهك يهزيدييهكان، شهبهك، كاكهييهكان،

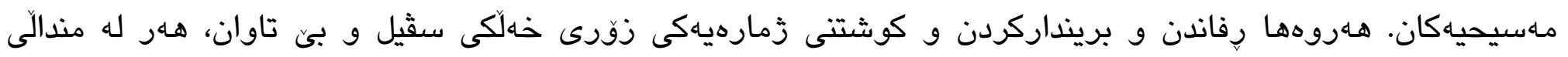

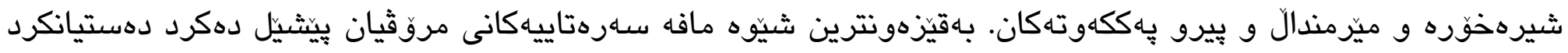

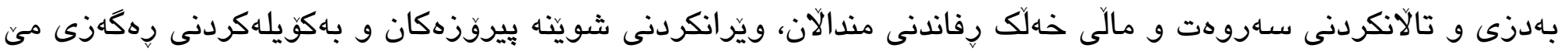




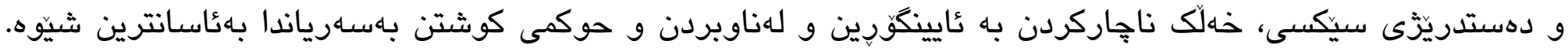

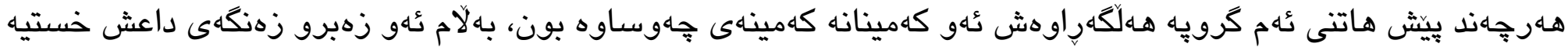

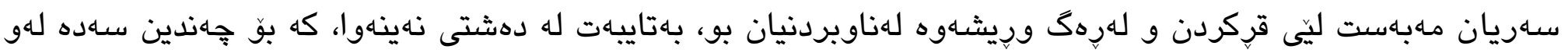
دهثهره زياون.

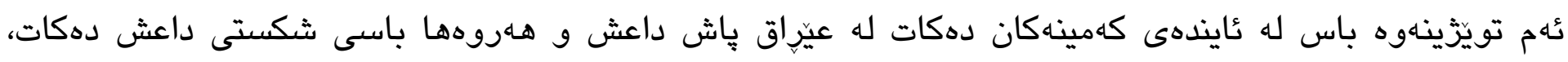

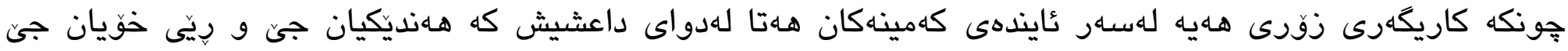

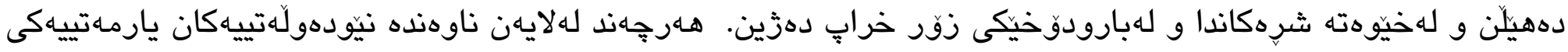

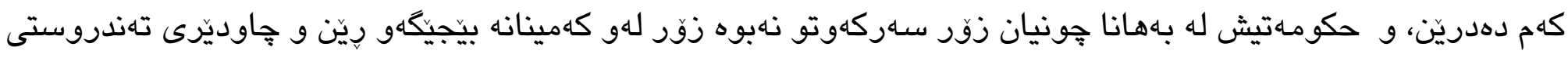

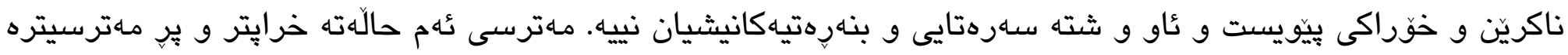

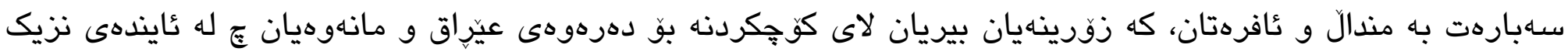

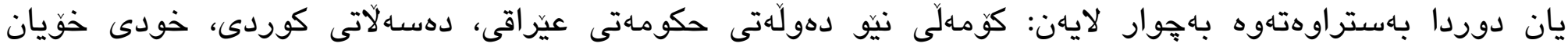

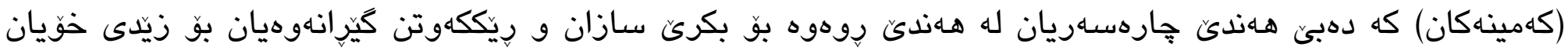
ياراستيان لههـمو دهستدريّزى و سوكايهتى يُيكردنيك له ئايندهدا لهبوارى ياساداناندا لهبوارى مافهكانى مروّثدا.

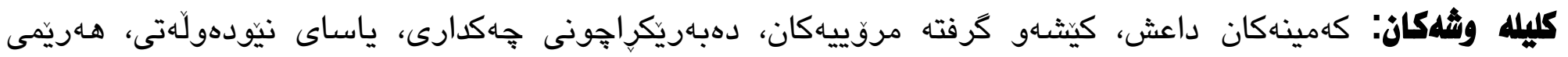
كوردستان، حكوماهتى فيدرالى عيّراقى. 


\section{References:}

Ali, M. H. (2017). Religious Minorities in Early Republican Iraq (1958-1968): Between Granting Rights and Discrimination, a Sociopolitical and Historical Study. Bamberg University, Germany.

Ali, M. H. (2019). Aspirations for Ethnonationalist Identities among Religious Minorities in Iraq: The Case of Yazidi Identity in the Period of Kurdish and Arab Nationalism, 1963-2003. Nationalities Papers, 47(6), 953-967.

Ali, M. H. (2019). The Controversy of the Religious Minorities Identities in Iraq: The Crystallization of the Yazidi Identity after 2003. British Journal of Middle Eastern Studies, 1 .

Cetorelli, V. and Ashraph, S. (2019). A demographic documentation of ISIS's attack on the Yazidi village of Kocho LSE Middle East Centre reports. LSE Middle East Centre, London, UK.

Crone, J. (June 5, 2015). “Christian family in ancient Iraqi city of Nineveh prepare to defend 2,700 year-old tomb of Jewish prophet, as ISIS armies advance to just 10 miles away.” mailOnline. Retrieved on January 14, 2019, from <<https://www.dailymail.co.uk/news/article-3112585/Christian-family-ancient-Iraqi-city-Nineveh-prepare-defend-2700-year-old-tomb-Jewish-prophet-ISIS-armies-advance-just-10-miles-away.html>> [Accessed 20 Jan. 2020].

Dewachi, O. (2017). Ungovernable Life: Mandatory Medicine and Statecraft in Iraq. Stanford, CA: Stanford University Press.

Dietrich, L. and Carter, S. E. (2017). Gender and Conflict Analysis in ISIS Affected Communities in Iraq. UN Women. Donabed, S. G. (2015). Reforging a Forgotten History: Iraq and the Assyrians in the Twentieth Century. Edinburgh: Edinburgh University.

Gardner, J. (2016). No Way Home: Iraq's minorities on the verge of disappearance. IILHR, MRG, NPWJ, UNPO. Joint CrISIL Coordination Centre KRG (2020) Over 1.5 million IDP and refugee individuals are registered in KRI. Available online <http://jcc.gov.krd/en/article/read/91>. [Accessed 20/11/2020].

Hanish, S. (2015). The Islamic State Effect on Minorities in Iraq. Review of Arts and Humanities, 4(1), 7-11. 
Helfont, S. (2018). Compulsion in Religion: Saddam Hussein, Islam, and the Roots of Insurgencies in Iraq. Oxford University Press.

Ibrahim, R. (October 28, 2018).” The Annihilation of Iraq's Christian Minority.” Gatestone Institute International Policy Council. Retrieved on January 14, 2019. Online https://www.gatestoneinstitute.org/13193/iraq-christians-annihilation. >. [Accessed 20/11/2020].

Iraq's Constitution of 2005. Available online $<<$ https://www.constituteproject.org/constitution/Iraq_2005.pdf?lang=en>>. >. [Accessed 20/11/2020].

Johnston, P. B., Alami, M. and Clarke, C. P. et al. (2019). Return and Expand? The Finances and Prospects of the Islamic State after the Caliphate. RAND Corporation.

Joint CrISIL Coordination Centre (2020). Over 1.5 million IDP and refugee individuals are registered in KRI. Online $<<$ http://jcc.gov.krd/en/article/read/235>>. [Accessed 20/11/2020].

Kaya, Z. (2019). Iraq's Yazidis and ISIL: the causes and consequences of sexual violence in conflict. LSE Middle East Centre, London, UK.

Millare, M. A. (2019). Defeating ISIL IN Iraq: A Race against Time. NCO Journal, 1-6 .

Mosul Study Group (2017). Mosul study group: What the Battle for Mosul teaches the force. Department of the Army. O’Driscoll, D. (2017). Autonomy Impaired: Centralisation, Authoritarianism and the Failing Iraqi State. Ethnopolitics 17(4), 315-322.

Oehring, O. (2017). Christians and Yazidis in Iraq: Current Situation and Prospects. Konrad-Adenauer-Stiftung. OCHA, (2020). Iraq: Humanitarian Dashboard for KRI (January to December 2019). Availabe online <https://reliefweb.int/report/iraq/iraq-humanitarian-dashboard-kri-january-december-2019>. [Accessed 15/11/2020]. Redvers, L. (2015). The crISIL in Iraq: an overview. Available online <https://odihpn.org/magazine/the-crISIL-in-iraqan-overview/>. [Accessed 15/11/2020]. 
Robinson, E., Egel, D. and Johnston, P. B. et al. (2017). Islamic State comes to town: The economic impact of Islamic State governance in Iraq and Syria. Rand

Rubaii, K. J. (2019). Tripartheid: How Sectarianism Became Internal to Being in Anbar, Iraq. American Anthropological Association, 42(1), 125-141.

Salloum, S. (2017). At Crossroads: Iraqi Minorities after ISIS. Baghdad: Heartland Alliance International.

Shea, N. (2016). The ISIL Genocide of Middle Eastern Christian Minorities and Its Jizya Propaganda Ploy. Center for Religious Freedom, Hudson Institute.

UNHCR (2019). International Protection Considerations with Regard to People Fleeing the Republic of Iraq. United Nations (UN) (August 2007). Office of the UN High Commissioner for Refugees (UNHCR). UNHCR's Eligibility Guidelines for Assessing the International Protection Needs of Iraqi Asylum-Seekers. [Accessed 12 Jan. 2020].

United Nations (UN) (20 JANUARY 2017) Security Council Press Statement on Destruction of Cultural Heritage, Executions in Palmyra. Online <https://www.un.org/press/en/2017/sc12690.doc.htm>. [Accessed 12 Jan. 2020]. Wainscot, A. (2019). Engaging the Post-ISIS Iraqi Religious Landscape for Peace and Reconciliation. United States Institute of Peace.

Zaman, A. (2016). From Tribe to Nation Final: Iraqi Kurdistan on the Cusp of Statehood. Wilson Center Middle East Program Occasional Paper Series. 